\title{
Implementation of E-Planning at The Padang Panjang Government
}

\author{
Falahuddin $^{1}$, Aldri Frinaldi ${ }^{2}$ \\ \{ falahuddin87@gmail.com ${ }^{1}$, aldri@fis.unp.ac.id² \\ State University of Padang ${ }^{1}$ \\ State University of Padang ${ }^{2}$
}

\begin{abstract}
Planning is a system that supports the preparation of regional development planning to make it more accurate, efficient, transparent, and accountable. So, the regional development planning that has been prepared can be carried out well. This study be carried out an analysis of the strategy for implementing an e-Planning-based regional development planning system at the Padang Panjang City Government. The method used is mixed methods, which combines two forms of qualitative and quantitative research. The research informants were the Head of BAPPEDA and his staff. Data collection was carried out by interview, questionnaire, and observation. Research methodology uses SWOT analysis and data validity test using a triangulation technique. The results showed that the strategies that have been implemented at BAPPEDA include: budget provision, increased stakeholder human resources, and clustering strategies. Related to the sequence of alternative strategies based on the results of QSPM calculations are: strengthening the commitment of local governments in budgeting, improving the quality of stakeholder HR, increasing readiness and commitment to implementing e-Planning, creating innovation, and developing systems that are easy to understand and the results of planning documents can be integrated with e-Planning.
\end{abstract}

Keywords : e-Planning, development planning

\section{Introduction}

Regional autonomy must be significant and strategic. The birth of the local government has the authority to regulate its own regional interests. Regional autonomy is an instrument for realizing people's welfare by optimizing the management of regional resource potentials. One form of governance is through the implementation of regional development, so an ideal development planning system is needed. Therefore, steps are required as stipulated in the Basic Law Number 25 of 2004 concerning the National Development Planning System, including the preparation of plans, determination of plans, control of plan executors, and evaluation of the implementation of plans[16]. Local governments need development planning that is accurate and accurate and is expected to evaluate the development being carried out.

According to the mandate of Government Regulation Number 8 of 2008 concerning stages, procedures for preparing, controlling and evaluating the implementation of regional development plans, Article 30 section 1 states the mandate " manage and utilize data and information optimally, regions need to build a planning information system. regional 
development"[17]. This is a logical consequence for developing an information system in the real of regional development planning. This is constrained if development planning is still carried out manually. In addition, Regional Apparatus Organizations usually experience difficulties in compiling development planning documents due to a lack of planning knowledge, both in the field of regulations regarding the preparation of planning documents, as well as from the support of performance data and budget achievement/realization. , difficulties in analyzing the achievement of performance over time, across regions, and relevance so that program and activity objectives have not been achieved as expected in accordance with the vision and mission of the organization in the OPD Strategic Plan document. Then the ineffective function of the regional development planning mechanism as a vehicle to integrate the bottom-up planning process with the top-down planning process.

Importance of an information system for regional development planning, the Padang Panjang City Government currently has a technique commonly called e-Planning means processing electronic data, collecting materials, compiling technical guidelines and instructions, and evaluating the implementation of regional government affairs in terms of planning regional development with the to increase effectiveness in the performance of regional development programs. e-Planning, which contains a menu for the Medium Term Development Planning (RPJMD) and the Government Work Plan (RKPD), which are manifested in the OPD Renstra and Renja accompanied by the reports used in the preparation of the document. This system controls the extent to which community equality is accommodated by the local government, starting from the proposal for musrenbang at the sub-district and sub-district level to those listed in the draft RKPD, which will become a reference in the preparation of OPD Renja. In general, the use of this system is a form of technical work in the development of e-Government management and the implementation of the Padang Panjang City Government in realizing the city as a Smart City. Consistency in regional development planning proposals is the ultimate goal of a system built to simplify the filling process, monitoring and controlling various development activities.

As a system that has only recently been implemented by the Government of Padang Panjang, various problems are still being found, especially the lack of readiness to implement the plan. At the beginning of the introduction of this system, BAPPEDA had indeed provided technical facilitation to facilitators at both the district and sub-district levels in Padang Panjang. However, there are still problems such as: lack of intensive training / socialization as provisions for those who program the system to parties who will later become input for regional development planning data in capturing community aspirations at the bottom up level. Then problems such as: a lack of level of understanding of human resources which includes employees within the scope of the Padang Panjang City Government and limited time in carrying out training / socialization, makes the theory transfer process by applying it to ePlanning. also less effective which causes not optimal in implementing the system. Is also known that the newly built structure is still not perfect to for accommoding all the aspirations of the community, namely the lack of a proposed dictionary available in the application, which often confuses application users, especially for the community at the Neighborhood to urban village.

\subsection{Literature Review \\ Development Planning}

Development planning comes from planning and development. In regional development, planning is the most important so that development can be carried out by with the wishes and ideals set, including its priorities [6]. Based on this understanding, it is necessary to 
know that planning, according to Alder [9], is a process of determining what to achieve in the future and determining the stages needed to achieve it. With planning, so that development will run appropriately according to the right sequence and taking into the available resources.

The reasons for planning in the development process are (a) Technological and scientific developments can change society more rapidly; (b) Planning is a critical stage when viewed from the development impact that will appear after the process is complete; (c) Planning can minimize the negative impacts of development; (d) The development process carried out certainly has limited time, cost and scope of implementation; and (e) Planning acts as a measure of the success of development implementation so that the development process can be monitored by related parties.

The aspects are of concern in development planning based on Widodo, 2006 [13] are: (a) Environmental aspects. Good planning must be able to capture environmental conditions in the area and environmental conditions in he regions that are partners in regional economic development; (b) Aspects of power and obstacles. A planner must have a description of everything the region has that can be a source of regional strength in carrying out development as well as weaknesses that have the potential to hinder the development process; (c) Aspects of the Central / Regional Development Planning Agency, the planning agency needs information about itself in the form of its role and function in regional development, its ability to develop development programs and its ability to obtain information needed to carry out regional planning. ; and (d) Spatial and temporal aspects, timeliness and place of implementation of development plans must be pursued by planners using a variety of current information.

Development planning also expects success in its implementation, the dimensions of success in achieving development planning goals according to Riyadi and Bratakusumah (2004)[8] are influenced by several factors, including: (a) Environment, these environmental factors can come from outside (external) and from within. (internal). ); (b) Human resource planners, human resource factors are the driving force of planning; (c) The system used, the system factor used is the regulation or policy used by a region / region as the basis for implementing its development planning; (d) The development of science and technology, scientific factors can exert influence not only in terms of equipment but also in the presence of various techniques and more advanced management approaches; and (e) Funding which is a factor that must exist to carry out an activity or activity.

\section{Information System}

The system according to Jogiyanto (2005)[2] is a network of interconnected procedures, gathered together to carry out an activity or to complete a specific goal. Meanwhile, information is defined as data that is processed into a form that is more useful and meaningful for those who receive it. According to Kadir (2003)[3] states that information is data that has been processed in such a way that it can increase the knowledge of someone who uses the data. Based on the understanding of systems and information, is defined that an information system is a system within an organization that meets the needs of daily transaction processing, supports operations, is managerial, and strategic activities of an organization and provides sure outsiders with the necessary reports[2].

According to Kadir (2003)[3], detail information system components can be described: (a) Hardware (hardware), including physical devices such as monitors and printers; (b) Software (software) or programs. A set of instructions that allow a hard disk to process data; (c) Procedure, a set of rules used to achieve data processing and correct the desired output; (d) Users, all parties responsible for the development of information systems, processing, and use 
of information system outputs. (e) Databases, which are collections of data that are interconnected with other data, are stored on computer hardware and used by software to manipulate data, users, and systems.

\section{Development Planning Information System}

The Regional Development Planning Information System (SIMPEPEDA) is an application to integrate the policies of the District Musrenbang, Renja, RKPD to KUA PPAS. With the SIMPEPEDA application, is hoped that all organizations, OPDs involved in the regional development planning process can compile plans in a standard format determined by the Minister of Home Affairs[14]. About to the duties of BAPPEDA as a development planning apparatus, an information system is needed implements the planning process so that it an encourage performance improvement, facilitate planning and data consolidation and facilitate consistency in planning and budget data management. This is a link between information systems and the regional planning management process [15].

The development of a Regional Development Planning Information System is carried out based on the need for transparency as part of the information on public transparency and accountability for development planning starting from the village/village level to the district/city level. The system built controls the extent to which community proposals can be accommodated by the Regional Government. This system was developed to be accessible to all DPOs related to the development planning process at all levels of the government system.

\section{e-Planning}

e-Planning is a system that supports the development planning process of an area. The way of preparing regional development planning is greatly facilitated by e-Planning because it has adopted the right information technology. The results of e-Planning include Regional Development Work Plans (RKPD), Regional Medium-Term Development Plans (RPJMD), Regional Apparatus Strategic Plans (Renstra PD), Regional Apparatus Work Plans (Renja PD), Priority Drafts and Temporary Budget Ceiling (RPPAS) and the Draft General Budget Policy (RKUA). e-Planning can make regional development planning more accurate, efficient, transparent, and accountable. Besides, e-Planning system in the process of preparing regional development planning will make it easier for Regional Apparatus Organizations (OPD) to optimize their performance. So that the regional development process that has been prepared can be carried out well.

\section{Strategy Theory}

According to Sukristono, as quoted by Umar (2001)[12], strategy is a process of determining the top leadership's plan which focuses on the long-term goals of the organization, accompanied by the preparation of methods or efforts to achieve these goals. Meanwhile, according to Hamel and Prahalad, the strategy is an action that is ncremential (always increasing) and continuous, It is carried out based on the point of view of what customers expect in the future. Thus, strategy almost always starts with what can happen and not what happens. The occurrence of new market innovation speeds and changing consumer patterns requires core competencies.

It can be concluded that strategy is a planning process carried out by top leaders with long-term goals that lead to developing of an effective strategy to help achieve the goals of an organization or company.

The Strategy Making Process, Thomson and Strickland (2001)[11] states that making 
a strategy or implementation process contains five interrelated managerial tasks: (a) Articulating the Vision and Mission. Vision is what the organization wants to be in the future. While the mission basically a statement about the general goals of the company/organization. (b) Formulating Objectives. The objective is to convert of the vision and mission that are elaborated into a specific performance target that the organization wants to achieve. This goal must be measurable so that in a certain period, its achievement can be evaluated. (c) Formulating a Strategy. System must determine the right choices and the best results for the company. Strategies must be able to match (fit and match) between the resources and capabilities of the company with external challenges and current and future competitive dynamics. (d) Strategy Implementation and Execution. The managerial task in implementing and executing strategies is to strive for how the organization can carry out these strategies so that organizational goals can be achieved within a predetermined time. (e) Performance Evaluation, Monitoring New Developments, and Initiating Corrective djusments. Leaders must have systems and instruments to evaluate internal developments and progress and monitor related and influential external developments

\section{Methodology}

Research on the Strategy for the Implementation of an e-Planning-based Regional Development Planning System at the Padang Panjang Government was conducted using mixed methods. This research's step by combining two pre-existing forms of research, are qualitative and quantitative research. This research was conducted at BAPPEDA Padang Panjang City as the OPD in charge of regional development planning. The scope of this regional development study activity is readiness in implementing e-planning based regional development planning.

The research's subjects were determined by using the purposive sampling technique, which is based on specific considerations. The research's ssue taken is a person who is considered to know a lot about what we expect or maybe he is the ruler, making it easier for researchers to be the object under study[10]. In connection with this research, the research subjects are (1) BAPPEDA is the leading sector or OPD in charge of implementing e-planning-based development planning, (2) BAPPEDA has the function of coordinating and verifying the regional development planning of Padang Panjang City, (3) Availability and convenience. Meanwhile, the research data sources are primary and secondary data.

Data collection techniques: questionnaires, interviews, observation, documentation, literature study, and online research (Library Research and Online Research). The data analysis technique uses SWOT, with: the following stages Identification of Internal and External Factors, Formulation of Questionnaires, data analysis with IFE and EFE Matrix Analysis, SWOT Matrix Analysis, QSP Matrix (Quantitative Strategies Planning Matrix), as well as checking the validity of the data by extending participation, persistence, observation, triangulation, through discussion, and checking members[1]. 


\section{Finding and Discussion}

\begin{tabular}{|c|c|c|c|}
\hline No & $\begin{array}{c}\text { Problem } \\
\text { Formulation }\end{array}$ & Concepts & Data and Analysis Results \\
\hline \multirow[t]{3}{*}{1.} & $\begin{array}{l}\text { Analysis of the } \\
\text { strategy for } \\
\text { implementing } \\
\text { the e-Planning- } \\
\text { based regional } \\
\text { development } \\
\text { planning } \\
\text { system that has } \\
\text { been carried out } \\
\text { by BAPPEDA } \\
\text { Kota Padang } \\
\text { Panjang? }\end{array}$ & $\begin{array}{l}\text { Strengths } \\
\text { (Strength) }\end{array}$ & $\begin{array}{l}\text { Data source : } \\
\text { Padang Panjang BAPPEDA } \\
\text { Renstra and Renja } \\
\text { The results of interviews } \\
\text { with echelon II and III } \\
\text { officials in the BAPPEDA } \\
\text { environment of Padang } \\
\text { Panjang City and the } \\
\text { author's observations in the } \\
\text { field to obtain SWOT } \\
\text { factors for Serambi-Plan e- } \\
\text { Planning in development } \\
\text { planning in Padang Panjang } \\
\text { City }\end{array}$ \\
\hline & & & $\begin{array}{l}\text { The results of the } \\
\text { questionnaire data } \\
\text { processing to get a Rating } \\
\text { score are not important, } \\
\text { elatively important, } \\
\text { important, and very } \\
\text { important }\end{array}$ \\
\hline & & $\begin{array}{l}\text { Weakness } \\
\text { (Kelemahan) }\end{array}$ & $\begin{array}{l}\text { Data source : } \\
\text { Padang Panjang BAPPEDA } \\
\text { Renstra and Renja }\end{array}$ \\
\hline
\end{tabular}

$\begin{array}{ll}\text { No } \begin{array}{c}\text { Problem } \\ \text { Formulation }\end{array} \quad \text { Concepts } & \text { Data and Analysis Results } \\ & \text { The results of interviews } \\ & \text { with echelon II and III } \\ & \text { officials in the BAPPEDA } \\ & \text { environment of Padang } \\ & \text { Panjang City and the } \\ & \text { author's observations in the } \\ & \text { field to obtain SWOT } \\ & \text { factors for the application } \\ & \text { of Serambi-Plan e-planning } \\ & \text { in development planning in } \\ & \text { Padang Panjang City }\end{array}$

1. The Planning and Reporting Subdivision in each Regional Apparatus Organization already has a specific job description as an e-Planning operator, with a total score of 0.29 (Results of IFE matrix analysis).

2. The content of e-Planning-based development planning, namely Serambi-Plan, is quite easy to understand and understand, with a total score of 0.33 (Results of IFE matrix analysis).

3. Guidelines are already available regarding the procedures and processes for e-Planning-based development planning on Serambi-Plan, with a total score of 0.40 (Results of IFE matrix analysis).

4. There is already a budgeting fund for human resource development, with a total score of 0.25 (Results of the IFE matrix analysis).

5. A computer (hardware) is available and its completeness in each of the Reporting Planning Subdivisions (operator e-planning) in each Regional Apparatus Organization, with a total score of 0.32 (Results of IFE matrix analysis).

1. Lack of staff qualifications in the Reporting Planning Subdivision as e-Planning operators in each Regional Apparatus Organization, with a total score of 0.19 (Results of IFE matrix analysis).

2. Lack of staff qualifications in the Reporting Planning Subdivision as e-Planning operators in each Regional Apparatus Organization, with a total score of 0.19 (Results of IFE matrix analysis).

3. The placement of employees who are not by the educational background to carry out the planning function, with a total score of 0.21 (Results of the IFE matrix analysis).

4. Lack of employee readiness when there is a demand for changes in the e-planning-based development planning process, namely Serambi-Plan Padang Panjang City, with a 
The results of the questionnaire data processing to get a Rating score are not important, quite important, important, and very important

Opportuniti es (opportuniti es)
Data source :

Padang Panjang BAPPEDA

Renstra and Renja

The results of interviews with echelon II and III officials in the BAPPEDA environment of Padang Panjang City and the author's observations in the field to obtain SWOT factors for the application of Serambi-Plan e-planning in development planning in Padang Panjang City

The results of the questionnaire data processing to get a Rating score are not important, quite important, important, and very important.

\begin{tabular}{|c|c|c|c|}
\hline No & $\begin{array}{c}\text { Problem } \\
\text { Formulation }\end{array}$ & Concepts & Data and Analysis Results \\
\hline & & $\begin{array}{l}\text { Threats } \\
\text { (threats) }\end{array}$ & $\begin{array}{l}\text { Data source : } \\
\text { Padang Panjang BAPPEDA } \\
\text { Renstra and Renja }\end{array}$ \\
\hline
\end{tabular}

The results of interviews total score of 0.15 (Results of IFE matrix analysis).

5. The equipment maintenance schedule for running irregular e-planning applications, with a total score of 0.20 (IFE matrix analysis results).

6. Lack of telecommunications media readiness for e-planning operations, with a total score of 0.24 (Results of IFE matrix analysis).

7. Lack of readiness of human resources for eplanning, with a total score of 0.18 (Results of IFE matrix analysis).

8. Lack of readiness of the Serambi-Plan Team to provide information to policymakers, with a total score of 0.25 (Results of IFE matrix analysis).

9. Lack of infrastructure readiness for e-Planning, with a total score of 0.24 (Results of IFE matrix analysis).

1. The implementation cycle of regional development planning has referred to the Regulation of the Minister of Home Affairs of the Republic of Indonesia Number 86 of 2017 and is by the material/content of e-planning, with a total score of 0.41 (Results of the IFE matrix analysis).

2. The manual format of the development planning document is by the e-planning input menu, with a total score of 0.40 (Results of the IFE matrix analysis).

3. The Padang Panjang City Government's commitment has begun to emerge in the implementing of e-planning-based development planning, with a total score of 0.42 (Results of IFE matrix analysis).

4. The Padang Panjang City Government is committed to implementing e-planning-based development planning by Permendagri Number 98 of 2018 concerning Regional Development Information Systems, with a total score of 0.56 (Results of the IFE matrix analysis).

\section{Reflection Analysis}

1. Serambi-Plan Kota Padang Panjang is an initial innovation in the use of e-planning based development planning. A lot of development is still needed, with a total score of 0.53 (Results of IFE matrix analysis). 
with echelon II and III officials in the BAPPEDA environment of Padang Panjang City and the author's observations in the field to obtain SWOT factors for implementing Serambi-Plan e-Planning in development planning in Padang Panjang City

The results of the QUESTIONARY data processing to get a Rating score are not important, quite important, important, and very important

2. Analysis of other alternative strategies in the application of an e-Planningbased regional development planning system by BAPPEDA

Kota Padang Panjang using QSPM matrix for SO, ST, WO, WT strategy development Data source :

The results of the SWOT analysis compare external factors, opportunities, and threats with internal factors, strengths, and weaknesses. Internal factors are included in the IFAS matrix (Internal Strategic Factor Analysis Summary). External factors are entered into the EFAS (External Strategic Factor Analysis Summary) matrix.
SWOT
2. The development planning process from the beginning to the preparation of planning documents (RPJMD, Renstra, RKPD, Renja, KUA PPAS, RKPD changes, etc.) has not been entirely computerized through Serambi-Plan, with a total score of 0.60 (Results of IFE matrix analysis).

3. Still, not all planning documents are produced from an integrated information system, For example, the RKPD for changes and Renja changes for the current years still compiled manually, with a total score of 0.60 (Results of IFE matrix analysis).

\section{SO strategy}

a. Adjustment of the e-planning input menu, namely Serambi-Plan, Padang Panjang City with guidelines that are easy to understand and understand by all e-planning operators. (S1, S2, S3, O1, O2)

b. Padang Panjang City Government's commitment to budgeting both human resources and infrastructure in implementing eplanning-based development planning in the City of Padang Panjang. (S4, S5, O3, O4)

\section{WO strategy}

a. Improve the quality of human resources, especially e-Planning operators, and avoid frequent transfers of structural and general functional officials who carry out planning functions at OPD. (W1, W2, W3, W4, W5, O1, $\mathrm{O} 2$ )

b. Increase the readiness of various things/factors to show commitment to e-Planning in regional development planning in Padang Panjang City. (W3, W4, W5, W6, W7, W8, O3, O4)

\section{ST strategy}

a. Budgeting to create innovations to improve human resources, information systems, and the infrastructure in implementing the SERAMBIPLAN e-planning in the City of Padang Panjang. ) S1, S2, S3, S4, S5, T1)

b. Increased e-planning as an integrated computerized system. (S2, S3, S5, T2, T3) 


\begin{tabular}{|c|c|c|c|}
\hline No & $\begin{array}{c}\text { Problem } \\
\text { Formulation }\end{array}$ & Concepts & Data and Analysis Results \\
\hline & & & $\begin{array}{l}\text { QSPM (Quantitative } \\
\text { Strategy Planning Matrix) } \\
\text { analysis for determining the } \\
\text { order of priority for the best } \\
\text { strategy. }\end{array}$ \\
\hline
\end{tabular}

\section{WT strategy}

a. Increase employee readiness to reduce incompetence in computerized systems. (W1, W2, W3, W4, W5, W6, W8, T1, T2)

b. Infrastructure readiness for all planning documents can be generated from an integrated information system. (W4, W8, T2, T3)

\section{QSPM results}

1. Strengthening the commitment of the Padang Panjang City government in budgeting both human resources and infrastructure in implementing e-planning-based development planning in the City of Padang Panjang, Total Accumulated Score (TAS) 2,895, Rank I

2. Improve the quality of human resources, especially e-planning operators, and the commitment of OPD leaders to avoid transfers of structural and general functional officials who carry out planning functions at OPD. Total Accumulated Score (TAS) 2,785, Rank II

3. Improve the readiness of various things/factors to show commitment to e-planning in regional development planning in the City of Padang Panjang. Total Accumulated Score (TAS) 2.7, Rank III

4. Increase employee readiness to reduce incompetence in computerized systems. . Total Accumulated Score (TAS) 2,455, Rank IV

5. Adjustment of the e-planning input menu, namely Serambi-Plan Padang Panjang City, with guidelines that are easy to understand and understand by all e-planning operators. Total Accumulated Score (TAS) 2.43, Rank V

6. Budgeting to create innovations to improve human resources, information systems, and infrastructure in implementing the SerambiPlan e-planing in the City of Padang Panjang. Total Accumulated Score (TAS) 2.22, Rank VI

7. Prepare facilities and infrastructure so that all planning documents can be produced from an integrated information system. Total Accumulated Score (TAS) 2.21, Rank VII

8. Increase the development of e-planning as an integrated computerized system. Total Accumulated Score (TAS) 2.09, Rank VIII 
Based on the results of the study, it can be seen that in terms of implementing regional development planning based on e-Planning Serambi-Plan in the City of Padang Panjang, several ways have been carried out, namely by: 1) Provision of the budget for system development, 2) Increasing Human Resources, 3) Strategy for Association of Regional Apparatus Organizations, 4) Increasing Resources for Related Stakeholders.

The results of this study are in line with Amstrong's (2008)[5] opinion which states that a SWOT analysis is a comprehensive assessment of the strengths, weaknesses, opportunities and threats of a company. This is also in line with the opinion of Rangkuti (2009) [7]which states that a SWOT analysis is a systematic identification of various factors to formulate a company strategy. Besides it is also by with the opinion of Kotler (2009)[4], which argues that SWOT analysis is a way to observe the external and internal marketing environment. In connection with the SWOT analysis carried out in this study, internal and external factors, both positive and negative, are then used to analyze the internal and external environment so that strengths, weaknesses, opportunities and strengths can be found. There are threats posed by BAPPEDA in or system the application of an e-Planning-Based Regional Development Planning System. Furthermore, it can be developed to obtain four kinds of strategies. Namely, SO strategy, ST strategy, WO strategy, WT strategy, so that it can provide a describe a descriptive form of situation analysis by the objectives of this study.

Based on the results of the study, it is known that the internal factors of BAPPEDA in the City of Padang Panjang in the Application of an e-Planning-Based Regional Development Planning System in the City of Padang Panjang, namely: Subdivision of Planning and Reporting in each OPD already has a specific job description as an e-Planning operator. e-Planning-based development, namely Serambi-Plan, is quite easy to understand and understand, Guidelines are available regarding procedures and processes for e-Planning-based development planning on Serambi-Plan, There is already budgeting for human resources development, computers (hardware) and their availability are available in each Reporting Planning Subdivision (ePlanning operator) in each OPD, Lack of staff qualifications in the Reporting Planning SubSection as an e-Planning operator in each Regional Apparatus Organization, Employee placement that is not in accordance with educational background to carry out the pe function plans, Lack of employee readiness when there are demands for changes in the e-Planning-based development planning process, namely the Serambi-Plan of Padang Panjang City, Schedule for equipment maintenance to run e-Planning applications that are irregular, Lack of readiness of telecommunications media for e-planning operations, Lack of resource readiness people for ePlanning, Lack of readiness of the Serambi-Plan Team to provide information to policymakers and Lack of willingness of infrastructure for e-Planning.

As well as it is also known the external factors of the application of the e-Planningbased Regional Development Planning System in the City Government of Padang Panjang, namely: The cycle of implementing regional development planning has referred to the Regulation of the Minister of Home Affairs of the Republic of Indonesia Number 86 of 2017, the manual format of development planning documents is in accordance with the input menu ePlanning, Padang Panjang City Government's commitment has begun to emerge in implementing e-Planning-based development planning, the Padang Panjang City Government is committed to implementing e-Planning-based development planning in accordance with Permendagri Number 98 of 2018 concerning Regional Development Information Systems, Serambi-Plan Padang Panjang City is an initial innovation in the use of e-Planning-based development planning and a lot of development is still needed, the development planning process from the beginning to the preparation of planning documents (RPJMD, Renstra, RKPD, 
Renja, KUA PPAS, RKPD Change etc.) has not been complete. It is done computerized through the Serambi-Plan, and not all planning documents have been produced from an integrated information system.

\section{Conclusion}

An alternative strategy in implementing an e-Planning-based regional development planning system by BAPPEDA Padang Panjang City is based on the results of QSPM calculations in the following order: 1) Strengthening the commitment of the Padang Panjang City government in budgeting both human resources and infrastructure in implementing development planning based on e-planning in the City of Padang Panjang. 2) Improve the quality of human resources, especially the e-planning and well as the commitment of OPD leaders to avoid transfers for structural and general functional officials who carry out planning functions in OPD. 3) Increase the readiness of various things/factors to show commitment to eplanning in regional development planning in the City of Padang Panjang. 4) Budgeting to create innovations to improve human resources, information systems, and infrastructure in implementing Serambi-Plan e-planning in the City of Padang Panjang. 5) Adjustment of the eplanning input menu, namely Serambi-Plan Padang Panjang City, with guidelines that are easy to understand and understand by all e-planning operators. 6) Budgeting to create innovations to improve human resources, information systems, and infrastructure in implementing SerambiPlan e-planning in the City of Padang Panjang. 7) Prepare infrastructure so that all planning documents can be produced from an integrated information system. 8) Increase the development of e-planning as an integrated computerized system.

\section{References}

[1] E. Barlian, Aktivitas Motorik Suku Anak Dalam Desa Muaro Kelis, Kecamatan Tengah Ilir, Kabupaten Tebo Provinsi Jambi. In Prosiding Seminar Nasional Pascasarjana Unsyiah, 2017.

[2] H. M. Jogiyanto, Analisis \& Desain Sistem Informasi. Yogjakarta: Andi Offset, 2005.

[3] A. Kadir, Pengenalan sistem informasi. Yogyakarta: Andi Offset, 2003.

[4] P. Kotler, Manajemen Pemasaran, Edisi 13. Jakarta: Erlangga, 2009.

[5] P. K. A. Armstrong, Prinsip-prinsip Pemasaran, Edisi 12 Jilid 1. Jakarta: Erlangga, 2008.

[6] L. Muta'ali, Perencanaan Pengembangan Wilayah Berbasis Pengurangan Risiko Bencana. Yogyakarta: Badan Penerbit Fakultas Geografi (BPFG, 2014.

[7] F. Rangkuti, Analisis SWOT Teknik Membedah Kasus Bisnis. Jakarta: PT. Gramedia Pustaka Utama, 2009.

[8] B. D. Riyadi, Perencanaan Pembangunan Daerah; Strategi Menggali Potensi Dalam Mewujudkan Otonomi Daerah. Jakarta: Gramedia, 2004.

[9] Rustiandi E, Saefulhakim, Sunsun, Panuju D. R., Perencanaan danPengembangan Wilayah. Jakarta: Crestpent Pres dan Yayasan Pustaka Obor Indonesia, 2011.

[10] Sugiyono, Metode Penelitian Kombinasi (Mixed Methods). Bandung: Alfabeta, 2013.

[11] A. A. Thompson Jr, A. J. Strickland III, and J. Gamble, Crafting and executing strategy: 
Text and readings, 17th ed. Maidenhead, England: McGraw Hill Higher Education, 2009.

[12] H. Umar, Metode Penelitian dan Aplikasi dalam Pemasaran. Jakarta: Gramedia Pustaka Umum, 2001.

[13] T. Widodo, Perencanaan Pembangunan: Aplikasi Komputer (Era OtonomiDaerah. Yogyakarta (ID: UPP STIM YKPN, 2006.

[14] "Technophoria Indonesia One Stop IT solution," Technophoria.co.id. [Online]. Available: https://technophoria.co.id/. [Accessed: 14-Apr-2020].

[15] "Global Intermedia Nusantara," Gi.co.id. [Online]. Available: https://www.gi.co.id/. [Accessed: 14-Apr-2020].

[16] Undang-Undang Nomor 25 Tahun 2004 tentang Sistem Perencanaan Pembangunan Nasional.

[17] Peraturan Pemerintah Nomor 8 tahun 2008 tentang Tahapan, Tata Cara Penyusunan, Pengendalian Dan Evaluasi Pelaksanaan Rencana Pembangunan Daerah. 